\title{
MEMIMPIN TIM SECARA EFEKTIF DAN OPTIMAL UNTUK DAPAT MENCAPAI KEBERHASILAN SERTA KESUKSESAN SEPERTI YANG DIINGINKAN OLEH PERUSAHAAN LEADING YOUR TEAM TO GREATNESS
}

\author{
Nicholas Wilson $^{1 *}$, Janny Rowena ${ }^{2)}$, Lilis Susilawaty ${ }^{3)}$, Lanang Diayudha ${ }^{4)}$, Stevani Helena ${ }^{5)}$, \\ Marina Pendi ${ }^{6}$ )
}

\author{
1),2),3),4),5),6) Program Studi Manajemen/Fakultas IImu Sosial dan Humaniora, Universitas Bunda Mulia
}

Diterima 10 Februari 2021 / Disetujui 26 Februari 2021

\begin{abstract}
Being able to achieve all of the goals that companies would like to achieve had been the main purpose that all companies in the world want to fulfill, in which, in order to achieve all of these success and goals, companies should be able to lead their teams properly, in which, there are 4 (four) essential factors which companies should fully and thoroughly understand in order to effectively lead all of thsee teams toward achieving the goals that the teams would like to achieve, in which, these four aspects are consisted of: companies' ability to show and practice leadership, companies' ability to understand the importance of teamwork and team building, companies ability to develop and execute all of the strategies effectively, and companies' thorough understanding regarding the methods of tackling or eliminating Silo Mentality. Therefore, this community service project was commenced in order to inform and present the importance of understanding all of these four factors to all of the individuals working within the company in order to enable these individuals (together with their teams) to achieve their goals. This community service activity was conducted in Alfa Land, in which, a total of 37 individuals working in Alfa Land were participating in this community service activity. Due to the COVID-19 pandemic, this community service project was conducted virtually through Zoom Meeting Conference Platform. After commencing this community service project, authors hope that all Individuals and Teams who are participating in this community service activity could further understand the importance of establishing and improving teamwork in order to enable the teams and the company to achieve all of the targets and objectives which the company would like to achieve
\end{abstract}

Keywords: Leadership; Teamwork; Team Building; Strategy Implementation; Silo Mentality; Community Services

\begin{abstract}
ABSTRAK
Mencapai tujuan ataupun target yang diinginkan oleh perusahaan merupakan hal utama yang ingin dicapai oleh setiap perusahaan, yang dimana, keberhasilan perusahaan di dalam mencapai target ini secara krusial ditentukan oleh kerja sama tim yang efektif guna mencapai tujuan bersama. Berkaitan dengan hal ini, maka terdapat 4 (empat) hal utama yang perlu dipahami secara mendalam oleh perusahaan guna memastikan bahwa memang suatu perusahaan mampu untuk membimbing seluruh tim-nya dengan baik, yang dimana, keempat aspek ini adalah: Kepemimpinan yang baik, Kerja Sama Tim serta Team Building yang baik, kemampuan perusahaan di dalam mengembangkan serta mengeksekusi seluruh strategi dengan efektif dan optimal, serta kemampuan perusahaan di dalam menghilangkan adanya mentalitas silo di dalam perusahana tersebut. Alhasil, berkaitan dengan hal tersebut, maka kegiatan Pengabdian Kepada Masyarakat (PKM) pada kali ini dilakukan guna memberikan penjelasan, penyuluhan serta pemahaman secara mendalam kepada pihak perusahaan terkait dengan pentingnya perusahaan memahami peranan krusial dari keempat faktor tersebut guna memastikan bahwa memang seluruh individu dan tim yang ada di perusahaan tersebut dapat bekerja secara bersama-sama guna mencapai tujuan yang diinginkan. Adapun kegiatan PKM ini dilakukan di Alfa Land secara Online melalui media Zoom, mengingat bahwa kondisi pandemi COVID-19 yang saat ini melanda Indonesia dan dunia membuat tidak dimungkinkannya kegiatan PKM dilakukan secara tatap muka. Selanjutnya, sebanyak 37 peserta PKM yang merupakan individu-individu yang bekerja di Alfa Land, berpartisipasi pada kegiatan PKM kali ini. Adapun setelah diselenggarakannya kegiatan PKM ini, maka penulis berharap bahwa seluruh Individu yang bekerja di Alfa Land dapat lebih memahami lagi pentingnya kerja sama tim yang optimal guna memastikan bahwa seluruh tim dapat bekerja secara efektif guna mencapai tujuan bersama yang diinginkan oleh perusahaan. Kata Kunci: Kepemimpinan, Kerjasama Tim, Team Building, Implementasi Strategi, Mentalitas Silo, PKM
\end{abstract}

*Korespondensi Penulis:

E-mail:wp8989@yahoo.com 


\section{PENDAHULUAN}

Kesuksesan merupakakan hal yang sudah pasti ingin diraih oleh setiap perusahaan di dunia ini, terlepas dari di industri manakah perusahaan tersebut melakukan aktivitas usaha ataupun bisnisnya, yang dimana, salah satu kriteria utama yang dapat menentukan apakah sebuah perusahaan dapat dikatakan sebagai perusahaan yang sukses ataupun tidak adalah berdasarkan apakah perusahaan tersebut telah mampu dan berhasil di dalam mencapai seluruh tujuan ataupun target yang diinginkan ataupun tidak. Hal ini dikarenakan hanya apabila seluruh target yang ingin dicapai oleh perusahaan telah terpenuhi dan ter-realisasikan dengan baik maka perusahaan tersebut dapat dikatakan sukses. Adapun berkaitan dengan hal ini, sekalipun perusahaan sudah mampu mencapai seluruh target serta tujuannya dengan baik, maka tetap saja perusahaan tersebut dituntut untuk dapat senantiasa mempertahankan serta meningkatkan hasil pencapaian ataupun kesuksesan yang telah diraih oleh perusahaan tersebut (Wilson et al., 2019).

Berikutnya, berkaitan dengan kemampuan serta kapabilitas perusahaan di dalam mencapai target ataupun tujuan yang telah dirancang oleh perusahaan, terdapat beberapa hal ataupun faktor yang dapat menentukan apakah perusahaan mampu dan berhasil di dalam mencapai target yang diinginkan ini, yang dimana, keempat hal ataupun faktor ini adalah:

1. Kemampuan Leadership ataupun Kepemimpinan yang baik yang dimiliki dan dipraktekkan oleh para Petinggi Perusahaan

2. Kerja Sama Tim (Teamwork) serta Proses Team Building yang baik yang ditunjukkan dan dimiliki oleh setiap tim yang berada di dalam perusahaan tersebut
3. Kemampuan perusahaan di dalam merancang, mengeksekusi, mengimplementasikan serta mengevaluasi setiap strategi yang dimiliki oleh perusahaan tersebut secara efektif

4. Kemampuan perusahaan di dalam menghindari, mengurangi ataupun mengeliminasi terjadinya Mentalitas Silo diantara para individu yang bekerja di perusahaan tersebut

Berkaitan dengan keempat hal diatas , maka dapat dipahami bahwa keempat hal tersebut merupakan aspek-aspek ataupun faktor-faktor penting yang harus betul-betul dipahami serta dipraktekkan secara nyata oleh setiap perusahaan, yang dimana pemahaman menyeluruh yang dimiliki oleh perusahaan terkait dengan keempat faktor ini bukan hanya dapat meningkatkan efektivitas kerja dari masing-masing tim yang ada di dalam perusahaan tersebut, namun juga guna memastikan bahwa memang seluruh tim yang bekerja di dalam perusahaan tersebut dapat bekerja secara bersama-sama guna mencapai tujuan akhir yang diinginkan oleh perusahaan. Namun, yang menjadi permasalahan adalah bahwa masih banyak perusahaan yang menganggap bahwa kualitas individual dari setiap karyawan yang bekerja di perusahaan itulah yang memang memiliki peranan penting serta krusial di dalam menentukan bagaimana pencapaian dari perusahaan tersebut di industri yang digelutinya. Hal ini dikarenakan banyak dari perusahaanperusahaan ini yang berpendapat bahwa ketika seorang individu memiliki tingkat kecerdasan ataupun bakat yang mumpuni, maka tanpa perlu didukung oleh tim pun, individu-individu ini tetap dapat menjalankan tugas ataupun pekerjaannya dengan baik dan maksimal.

Adapun sebenarnya, dapat dipahami bahwa persepsi ini dapat dikatakan kurang tepat ataupun kurang benar, yang dimana, salah satu hal yang dapat menentukan keberhasilan dari setiap perusahaan adalah bagaimana masing-masing individu ini dapat 
mengesampingkan ego nya masing-masing, dapat mengesampingkan preferensi ataupun kepentingan pribadinya masing-masing, untuk individu-individu ini dapat bekerja secara bersama-sama dengan para individu lainnya di dalam suatu tim agar dapat mencapai goals ataupun target akhir yang ingin perusahaan tuju. Dengan demikian, maka kemampuan dari masing-masing Individu serta perusahaan di dalam membentuk sebuah tim yang efektif (Team Building), serta kemampuan dari perusahaan serta masing-masing individu di dalam menunjukkan kerja sama tim (Teamwork) yang optimal merupakan salah satu aspek yang dapat membawa perusahaan ke gerbang keberhasilan seperti yang ingin dicapai oleh perusahaan.

Adapun selain teamwork serta team building yang baik, kemampuan leadership ataupun kepemimpinan yang ditunjukkan dan dimiliki oleh para pemimpin dari perusahaan ataupun suatu tim di dalam perusahaan tersebut juga memegang peranan yang sangat penting di dalam menentukan arah ataupun tujuan yang ingin dicapai oleh tim serta perusahaan tersebut. Leadership ataupun kepemimpinan ini sendiri dapat dipahami sebagai sebuah konsepsi dasar yang menjelaskan kemampuan dari seorang individu, bukan hanya di dalam memberitahu individu-individu lainnya yang berada di posisi dibawahnya, namun juga berkaitan dengan kemampuan dari individu tersebut di dalam membina, membimbing serta mengarahkan individu-individu tersebut guna berkembang ke arah yang lebih baik lagi di dalam bidang karir ataupun pekerjaan yang sedang digeluti (jumalo \& Scheepers, 2020; Jaafaripooyan et al., 2020; Jacobsen \& Salomonsen, 2020; Goswami et al., 2020). Dengan demikian, maka dapat dipahami bahwa konsepsi dasar dari kepemimpinan ataupun leadership ini cenderung sangat berbeda jauh dengan konsepsi dasar dari seorang Bos. Hal ini dikarenakan seorang pemimpin (Leader) bukanlah semata-mata hanya bertugas di dalam memberikan perintah saja kepada individu-individu yang berada di posisi di bawahnya, namun juga pemimpin tersebut bertanggung jawab di dalam mengarahkan ataupun membimbing seluruh individu yang berada di posisi di bawahnya, bukan hanya guna memahami secara mendalam terkait dengan bidang pekerjaan yang dikerjakannya, namun juga guna memastikan bahwa memang talenta, kemampuan serta jenjang karir yang dimiliki oleh individu-individu tersebut dapat berkembang ke arah yang lebih baik lagi di masa yang akan datang (Manning \& Roberstson, 2016; Allio, 2016).

Dengan demikian, maka dapat dipahami bahwa kemampuan ataupun sikap kepemimpinan yang kuat yang dimiliki oleh para petinggi ataupun pemimpin dari setiap perusahaan inilah yang memiliki peranan yang besar dan krusial di dalam menentukan sebaik apakah kinerja yang ditunjukkan oleh seluruh tim di dalam perusahaan tersebut, serta di dalam menentukan keberhasilan serta kesuksesan perusahaan di dalam menggapai ataupun mencapai target yang telah dibuat dan direncanakan untuk dipenuhi oleh perusahaan tersebut.

Adapun berikutnya, selain pentingnya konsepsi dasar dari kerja sama tim, team building ataupun kepemimpinan di dalam menentukan keberhasilan ataupun kesuksesan dari sebuah perusahaan, kemampuan perusahaan di dalam merancang, mengimplementasikan serta meng-evaluasi setiap strategi yang dibuat dan dimiliki oleh perusahaan merupakan langkah berikutnya yang penting untuk dapat dipahami secara mendalam, serta dipraktekkan oleh setiap perusahaan guna memastikan bahwa memang apa yang diharapkan oleh perusahaan dari implementasi strategi yang telah dilakukan dapat berjalan sesuai dengan apa yang diharapkan oleh pihak perusahaan. Selain itu juga, beberapa penelitian terdahulu juga telah menemukan korelasi kuat dan signifikan antara efektivitas implementasi strategi perusahaan dengan keberhasilan perusahaan 
di dalam suatu industri, yang dimana, efektivitas dari strategi yang diimplementasikan oleh suatu perusahaan memiliki peranan yang penting, positif serta signifikan di dalam menentukan arah yang ingin dituju oleh perusahaan, serta di dalam menentukan ketercapaian target yang telah dirancang oleh perusahaan. Adapun nantinya, ketercapaian dari target perusahaan inilah yang dapat dijadikan sebagai acuan terkait dengan apakah perusahaan dianggap telah berhasil mencapai kesuksesannya ataupun tidak di dalam industri yang digeluti oleh perusahaan tersebut. Selain itu juga, Omondi et al., (2013) juga mengemukakan bahwa strategi yang secara optimal diimplementasikan oleh perusahaan dapat menjadi competitive advantage yang dapat membantu perusahaan tersebut di dalam bersaing secara efektif dengan seluruh kompetitor yang harus dihadapi di dalam suatu industri (Zubairu et al., 2021).

Selain implementasi strategi yang efektif, kesuksesan dari suatu perusahaan juga dapat ditentukan dari keberhasilan perusahaan di dalam mengeliminasi ataupun mengatasi problematika dari terjadinya Mentalitas Silo diantara para individu, tim ataupun divisi di dalam perusahaan tersebut. Adapun Mentalitas Silo ini dapat dipahami sebagai suatu konsepsi yang menjelaskan perihal tendensi yang dimiliki oleh seorang individu, sebuah tim ataupun sebuah divisi untuk tidak mau melaporkan, menyampaikan ataupun membagikan berbagai informasi yang dimiliki kepada divisi, tim ataupun individu lainnya (Forsten-Astikainen et al., 2017). Dengan kata lain, maka mentalitas silo ini cenderung terjadi ketika satu divisi dengan divisi lainnya cenderung menutup-nutupi informasi dari pihak lainnya, serta masingmasing divisi ataupun tim ini cenderung tidak mau untuk membagikan informasi-informasi penting kepada divisi ataupun tim lainnya. Tentu saja, hal ini menjadi suatu permasalahan yang cukup besar, serta beresiko di dalam "meruntuhkan" komunikasi serta tingkat kepercayaan yang dimiliki oleh satu divisi terhadap divisi lain ataupun tim yang ada di dalam perusahaan tersebut. Padahal, penting bagi setiap tim ataupun divisi untuk dapat membagikan berbagai informasi-informasi penting yang mungkin dapat bermanfaat, ataupun mungkin dibutuhkan oleh individu yang berasal dari tim ataupun divisi lainnya yang ada di dalam perusahaan tersebut.

Alhasil, dengan demikian, maka penting bagi perusahaan untuk dapat mengeliminasi terjadinya Mentalitas Silo ini, mengingat bahwa memang bukan hanya dapat merusak ataupun mengganggu hubungan komunikasi serta kepercayaan yang dimiliki antar individu serta antar divisi di dalam perusahaan tersebut, namun juga Mentalitas Silo ini dapat berpotensi "menjatuhkan" perusahaan tersebut apabila dibiarkan tanpa adanya solusi untuk waktu yang lama.

Dengan demikian, berdasarkan pemaparan yang telah penulis jabarkan pada latar belakang diatas, maka penulis memutuskan untuk mengadakan kegiatan pengabdian Kepada Masyarakat dengan Tema "Leading Your Team to Greatness" di Alfa Land secara Online melalui media Zoom.

\section{METODE PENELITIAN}

\section{Metode Penyelenggaraan dan Realisasi Kegiatan}

Adapun dikarenakan oleh Pandemi COVID-19 yang saat ini masih sedang terjadi dan melanda Indonesia, maka tidak memungkinkan untuk Kegiatan Pengabdian Kepada Masyarakat (PKM) ini dilakukan secara tatap muka secara langsung di lokasi yang telah dituju, sehingga, kegiatan dan pelaksanaan dari aktivitas Pengabdian Kepada Masyarakat (PKM) ke Alfa Land ini 
pun dilakukan secara online dan Virtual melalui media Zoom.

\section{Profil Peserta Kegiatan}

Adapun kegiatan Pengabdian Kepada Masyarakat ini dilakukan di Alfa Land, yang dimana, sebanyak 37 Peserta PKM yang berpartisipasi pada kegiatan PKM kali ini merupakan para Individu yang bekerja di Alfa Land, serta menempati berbagai posisi Jabatan pada perusahaan Alfa Land ini, mulai dari Staff hingga Direktur. Adapun rentang usia dari para peserta kegiatan PKM ke Alfa Land pada kali ini berkisar antara 23 tahun hingga 52 tahun. Selain itu juga, tingkat pendidikan dari

\section{Sesi Penyelenggaraan Kegiatan PKM}

Adapun kegiatan ini berlangsung selama kurang lebih 2 jam, yang dimana, kegiatan ini dibagi ke dalam 4 (empat) sesi utama, yang dimana, masing-masing sesi akan dipimpin oleh setiap dosen ataupun presenter materi yang berbeda satu dengan yang lainnya. Kegiatan ini sendiri dipimpin oleh Bapak Lanang Diayudha, S.E., M.Env.Mgt selaku Moderator pada kegiatan PKM pada kali ini. Adapun pada sesi pertama, Ibu Janny Rowena, S.E., M.M. selaku salah satu presenter dan instruktur pada kegiatan Pengabdian Kepada Masyarakat (PKM) pada kali ini membawakan materi terkait dengan konsepsi dasar dari Kepemimpinan (Leadership), yang dimana, setelah berakhirnya sesi pertama ini, maka kegiatan Pengabdian Kepada Masyarakat (PKM) ini akan dilanjutkan dengan pemaparan materi yang dipimpin serta disampaikan oleh Bapak Nicholas Wilson, S.E., M.M. pada sesi kedua, yang dimana, pada sesi ini, Bapak Nicholas selaku salah satu pembicara dan pemateri pada kegiatan PKM kali ini memaparkan materi perihal konsepsi dasar dari Teamwork dengan Team Building, serta konsepsi dasar dari apa yang dimaksud dengan strategi, serta pentingnya proses controlling ataupun evaluasi terhadap strategi yang telah diimplementasikan tersebut guna memastikan bahwa memang strategi yang telah dirancang sesuai dengan target yang diinginkan oleh perusahaan tersebut

Adapun berikutnya, pada sesi ketiga Ibu Lilis Susilawaty, S.E., M.M. menyampaikan materi perihal konsepsi dasar dari Mentalitas Silo, yang dimana, Ibu Lilis menyampaikan materi secara mendalam terkait dengan konsepsi dasar dari Mentalitas Silo ini. Adapun terakhir, pada sesi keempat ataupun di sesi yang terakhir, akan diadakan sesi Kuis, Diskusi, serta Tanya Jawab yang dipimpin oleh Bapak Lanang Diayudha, S.E., M.Env.Mgt, yang dimana sesi diskusi dan tanya jawab ini dilakukan berkaitan dengan materi-materi yang telah dipaparkan pada kegiatan PKM kali ini. Adapun setelah kegiatan Pengabdian Kepada Masyarakat (PKM) ini selesai dilakukan, maka setiap peserta seminar akan mengisi Kuesioner terkait dengan response ataupun penilaian yang diberikan oleh masing-masing peserta terkait dengan bagaimana kualitas dari materi yang telah disampaikan, serta terkait dengan bagaimana kemampuan dari masing-masing pembicara di dalam menyampaikan materi pada kegiatan Pengabdian Kepada Masyarakat (PKM) pada kali ini.

\section{HASIL DAN PEMBAHASAN}

\section{Pelaksanaan Kegiatan}

Kegiatan Pengabdian Kepada Masyarakat (PKM) ini berlangsung selama kurang lebih 2 jam, yang dimana, kegiatan ini dibagi ke dalam 4 (empat) sesi utama, yang dimana, masing-masing sesi akan dipimpin oleh setiap dosen ataupun presenter materi yang berbeda satu dengan yang lainnya. Kegiatan ini sendiri dipimpin oleh Bapak Lanang Diayudha, S.E., M.Env.Mgt selaku Moderator pada kegiatan PKM pada kali ini. Adapun pada sesi pertama, Ibu Janny Rowena, S.E., M.M. selaku salah satu presenter dan instruktur pada kegiatan 
Pengabdian Kepada Masyarakat (PKM) pada kali ini membawakan materi terkait dengan konsepsi dasar dari Kepemimpinan (Leadership), yang dimana, pada sesi ini, Ibu Janny memberikan pemaparan serta argumentasi yang mendalam terkait dengan apa yang dimaksud dengan Kepemimpinan (Leadership), hal-hal apa sajakah yang membedakan seorang Leader dengan seorang Boss, serta pentingnya peranan dari seorang Leader yang baik di dalam memimpin seluruh anggota perusahaan, tim serta perusahaan itu sendiri guna mencapai target ataupun tujuan yang ingin dicapai oleh perusahaan tersebut.

Adapun setelah sesi pertama ini, maka kegiatan Pengabdian Kepada Masyarakat (PKM) ini pun kembali dilanjutkan dengan pemaparan materi yang dipimpin serta disampaikan oleh Bapak Nicholas Wilson, S.E., M.M. pada sesi kedua, yang dimana, pada sesi ini, Bapak Nicholas selaku salah satu pembicara dan pemateri pada kegiatan PKM kali ini memaparkan materi perihal konsepsi dasar dari Teamwork dengan Team Building, perbedaan antara kedua konsep ini, serta mengapa penting bagi setiap perusahaan di dalam memahami secara mendalam terkait dengan kedua konsep ini. Selain itu juga, Bapak Nicholas juga memberikan pemaparan materi yang mendalam terkait dengan konsepsi dasar dari apa yang dimaksud dengan strategi, mengapa penting bagi setiap perusahaan di dalam memahami tahapan-tahapn penting di dalam membuat strategi secara mendalam, yang dimana, proses pembuatan strategi ini dimulai dari proses perancangan, proses implementasi, serta proses controlling ataupun evaluasi terhadap strategi yang telah diimplementasikan tersebut guna memastikan bahwa memang strategi yang telah dirancang dan diimplementasikan oleh perusahaan dapat menjadi alat yang tepat bagi perusahaan guna mencapai tujuan ataupun target yang diinginkan oleh perusahaan tersebut

Adapun berikutnya, pada sesi ketiga

Ibu Lilis Susilawaty, S.E., M.M. menyampaikan materi perihal konsepsi dasar dari Mentalitas Silo, yang dimana, selain menjelaskan perihal konsepsi dasar ataupun pengertian dari Mentalitas Silo ini, Ibu Lilis juga mengemukakan pentingnya perusahaan untuk dapat selalu dan senantiasa memastikan bahwa seluruh divisi atapun tim di dalam suatu perusahaan cenderung terbebas dari Mentalitas Silo ini. Hal ini dikarenakan apabila dibiarkan terus-menerus tanpa adanya usaha dari perusahaan untuk mengeliminasi Mentalitas Silo ini, maka tinggi resikonya bagi perusahaan untuk "terjatuh" dikarenakan oleh retaknya hubungan komunikasi antar divisi, tim ataupun individu di dalam perusahaan tersebut yang disebabkan oleh Mentalitas Silo ini.

Adapun berikutnya, pada sesi keempat ataupun di sesi yang terakhir, diadakan sesi Kuis, Diskusi, serta Tanya Jawab yang dipimpin oleh Bapak Lanang Diayudha, S.E., M.Env.Mgt, yang dimana sesi diskusi dan tanya jawab ini dilakukan berkaitan dengan keseluruhan materi, pemaparan serta penalaran yang telah disampaikan pada kegiatan Pengabdian Kepada Masyarakat (PKM) kali ini.

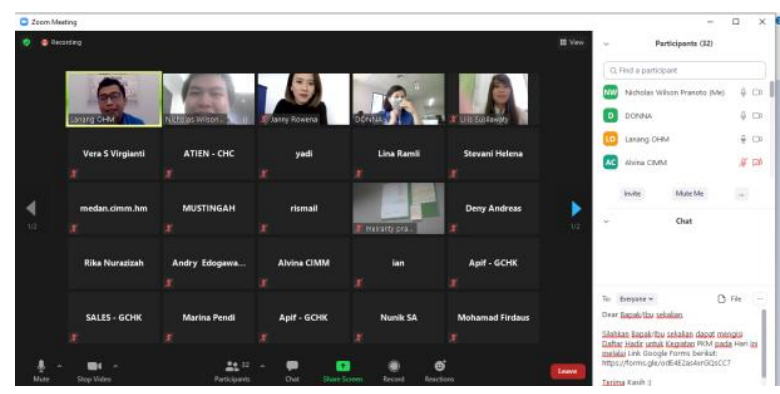

Gambar 1. Pelaksanaan Kegiatan Pengabdian Kepada Masyarakat (PKM) ke Alfa Land yang dilakukan secara Online melalui Media Zoom 


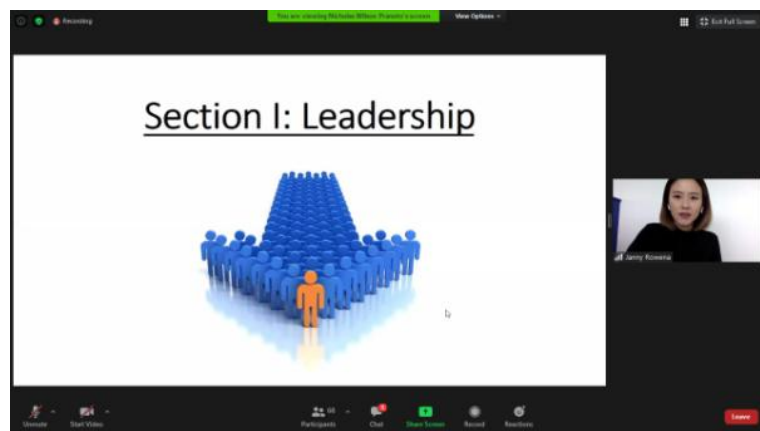

Gambar 2. Presentasi Materi yang disampaikan oleh Ibu Janny Rowena, S.E., M.M. selaku salah satu Pembicara pada Kegiatan Pengabdian Kepada Masyarakat (PKM) ke Alfa Land pada Kali Ini

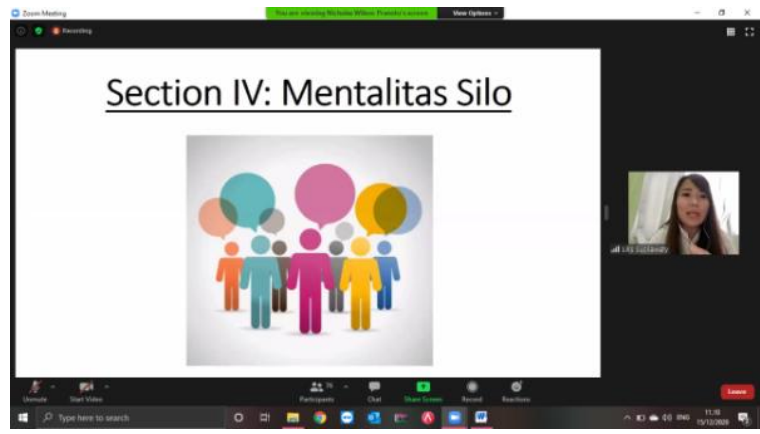

Gambar 3. Presentasi Materi yang disampaikan oleh Ibu Lilis Susilawaty, S.E., M.M. selaku salah satu Pembicara pada Kegiatan Pengabdian Kepada Masyarakat (PKM) ke Alfa Land pada Kali Ini

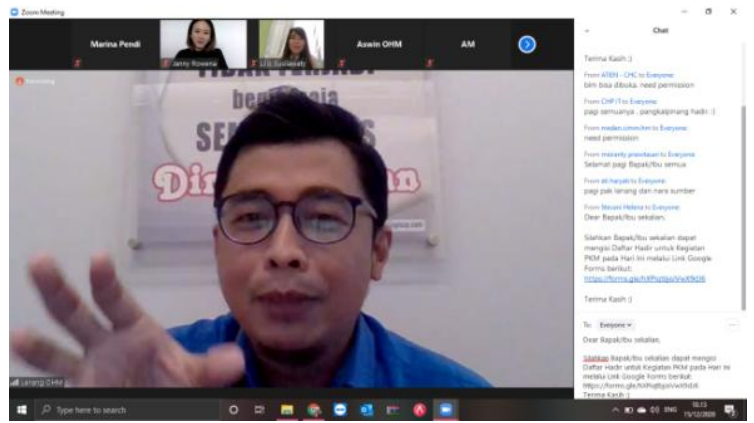

Gambar 4. Presentasi Materi yang disampaikan oleh Bapak Lanang Diayudha, S.E., M.Env.Mgt selaku Moderator dan salah satu Pembicara pada Kegiatan Pengabdian Kepada Masyarakat (PKM) ke Alfa Land pada Kali Ini

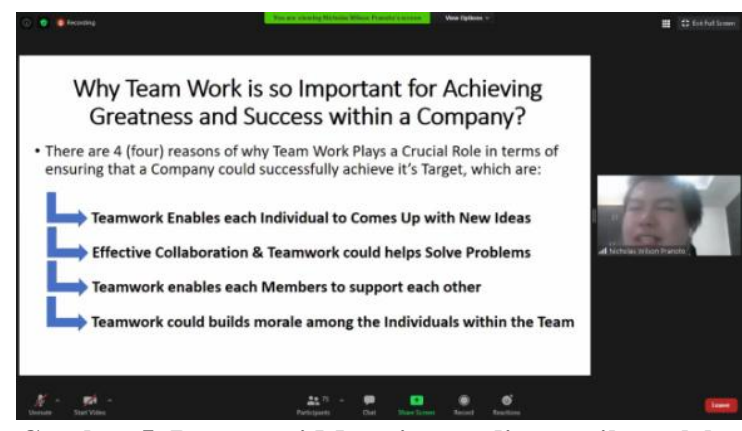

Gambar 5. Presentasi Materi yang disampaikan oleh Bapak Nicholas Wilson, S.E., M.M. selaku salah satu Pembicara pada Kegiatan Pengabdian Kepada Masyarakat (PKM) ke Alfa Land pada Kali Ini

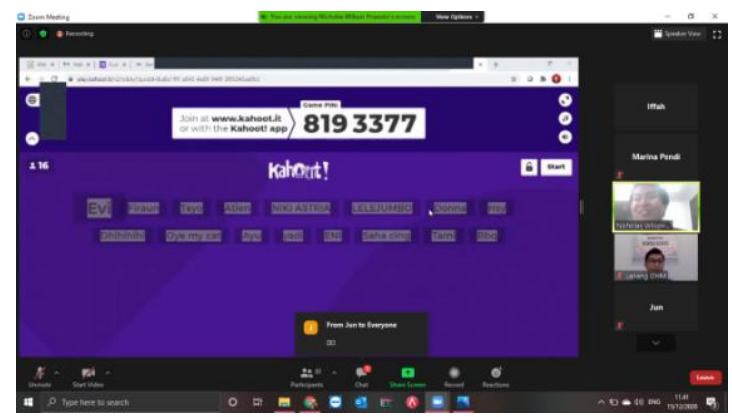

Gambar 6. Sesi Games dan Kuis yang diadakan pada sesi Akhir Kegiatan Pengabdian Kepada Masyarakat (PKM) ke Alfa Land pada Kali Ini

\section{Hasil Penilaian Peserta}

Adapun setelah kegiatan Pengabdian Kepada Masyarakat dengan tema "Leading Your Team to Greatness" ini selesai dilakukan, maka masing-masing peserta akan diberikan kuesioner untuk diisi, yang dimana, kuesioner ini pun digunakan sebagai wadah bagi para peserta kegiatan Pengabdian Kepada Masyarakat (PKM) pada kali ini guna menilai bagaimana kualitas dari Materi yang telah disampaikan, serta guna menilai bagaimana kualitas, ketangkasan serta kemampuan penguasaan materi yang ditunjukkan oleh pembicara ataupun instruktur pada kegiatan Pengabdian Kepada Masyarakat (PKM) pada kali ini. Adapun hasil dari Kuesioner yang telah diisi oleh para peserta ditampilkan pada Tabel 1 hingga tabel 8 di bawah ini. 
Tabel 1. Hasil Pengisian Kuesioner Peserta PKM

(Untuk Materi yang Disampaikan) - Ibu Janny Rowena, S.E., M.M.

\begin{tabular}{|c|c|c|}
\hline No. & Kriteria & $\begin{array}{c}\text { Nilai } \\
\text { Rata- } \\
\text { Rata }\end{array}$ \\
\hline 1. & $\begin{array}{c}\text { Manfaat Materi Bagi } \\
\text { Peserta }\end{array}$ & 3.38 \\
\hline 2. & $\begin{array}{c}\text { Relevansi Materi Dengan } \\
\text { Tujuan Kegiatan }\end{array}$ & $\mathbf{3 . 6 8}$ \\
\hline 3. & $\begin{array}{c}\text { Ketepatan Media Atau } \\
\text { Sarana Yang Digunakan } \\
\text { Oleh Narasumber }\end{array}$ & 3.46 \\
\hline 4. & $\begin{array}{c}\text { Proses Atau Kegiatan } \\
\text { Pelaksanaan }\end{array}$ & 3.51 \\
\hline 5. & $\begin{array}{c}\text { Penambahan } \\
\text { Pengetahuan/Keterampilan } \\
\text { yang Dapat Diaplikasikan }\end{array}$ & $\mathbf{3 . 7 0}$ \\
\hline
\end{tabular}

Tabel 2. Hasil Pengisian Kuesioner Peserta PKM (Untuk Narasumber) - Ibu Janny Rowena, S.E., M.M.

\begin{tabular}{|c|c|c|}
\hline No. & Kriteria & $\begin{array}{c}\text { Nilai } \\
\text { Rata- } \\
\text { Rata }\end{array}$ \\
\hline 1. & $\begin{array}{c}\text { Kemampuan Atau } \\
\text { Penguasaan Terhadap } \\
\text { Materi }\end{array}$ & 3.76 \\
\hline 2. & $\begin{array}{c}\text { Kemampuan Dalam } \\
\text { Menyampaikan Materi }\end{array}$ & 3.57 \\
\hline 3. & $\begin{array}{c}\text { Kemampuan } \\
\text { Menggunakan Metode } \\
\text { Yang Tepat Dengan Materi }\end{array}$ & 3.81 \\
\hline 4. & $\begin{array}{c}\text { Kemampuan Dalam } \\
\text { Menjawab Pertanyaan } \\
\text { Peserta }\end{array}$ & 3.62 \\
\hline 5. & $\begin{array}{c}\text { Kemampuan Menciptakan } \\
\text { Suasana Yang Mendukung } \\
\text { Kegiatan }\end{array}$ & 3.59 \\
\hline
\end{tabular}

Tabel 3. Hasil Pengisian Kuesioner Peserta PKM

(Untuk Materi yang Disampaikan) - Ibu Lilis Susilawaty, S.E., M.M.

\begin{tabular}{|c|c|c|}
\hline No. & Kriteria & $\begin{array}{c}\text { Nilai } \\
\text { Rata- } \\
\text { Rata }\end{array}$ \\
\hline 1. & Manfaat Materi Bagi & $\mathbf{3 . 4 6}$ \\
\hline
\end{tabular}

\begin{tabular}{|c|c|c|}
\hline & Peserta & \\
\hline 2. & $\begin{array}{c}\text { Relevansi Materi Dengan } \\
\text { Tujuan Kegiatan }\end{array}$ & 3.51 \\
\hline 3. & $\begin{array}{c}\text { Ketepatan Media Atau } \\
\text { Sarana Yang Digunakan } \\
\text { Oleh Narasumber }\end{array}$ & 3.54 \\
\hline 4. & $\begin{array}{c}\text { Proses Atau Kegiatan } \\
\text { Pelaksanaan }\end{array}$ & $\mathbf{3 . 4 6}$ \\
\hline 5. & $\begin{array}{c}\text { Penambahan } \\
\text { Pengetahuan/Keterampilan } \\
\text { yang Dapat Diaplikasikan }\end{array}$ & $\mathbf{3 . 5 1}$ \\
\hline
\end{tabular}

Tabel 4. Hasil Pengisian Kuesioner Peserta PKM (Untuk Narasumber) - Ibu Lilis Susilawaty, S.E., M.M.

\begin{tabular}{|c|c|c|}
\hline No. & Kriteria & $\begin{array}{c}\text { Nilai } \\
\text { Rata- } \\
\text { Rata }\end{array}$ \\
\hline 1. & $\begin{array}{c}\text { Kemampuan Atau } \\
\text { Penguasaan Terhadap } \\
\text { Materi }\end{array}$ & 3.59 \\
\hline 2. & $\begin{array}{c}\text { Kemampuan Dalam } \\
\text { Menyampaikan Materi }\end{array}$ & $\mathbf{3 . 5 1}$ \\
\hline 3. & $\begin{array}{c}\text { Kemampuan } \\
\text { Menggunakan Metode } \\
\text { Yang Tepat Dengan Materi }\end{array}$ & $\mathbf{3 . 6 8}$ \\
\hline 4. & $\begin{array}{c}\text { Kemampuan Dalam } \\
\text { Menjawab Pertanyaan } \\
\text { Peserta }\end{array}$ & $\mathbf{3 . 5 1}$ \\
\hline 5. & $\begin{array}{c}\text { Kemampuan Menciptakan } \\
\text { Suasana Yang Mendukung } \\
\text { Kegiatan }\end{array}$ & $\mathbf{3 . 5 1}$ \\
\hline
\end{tabular}

Tabel 5. Hasil Pengisian Kuesioner Peserta PKM

(Untuk Materi yang Disampaikan) - Bapak Nicholas Wilson, S.E., M.M.

\begin{tabular}{|c|c|c|}
\hline No. & Kriteria & Nilai \\
\hline
\end{tabular}




\begin{tabular}{|c|c|c|}
\hline & & $\begin{array}{l}\text { Rata- } \\
\text { Rata }\end{array}$ \\
\hline 1. & $\begin{array}{c}\text { Manfaat Materi Bagi } \\
\text { Peserta }\end{array}$ & 3.68 \\
\hline 2. & $\begin{array}{c}\text { Relevansi Materi Dengan } \\
\text { Tujuan Kegiatan }\end{array}$ & 3.78 \\
\hline 3. & $\begin{array}{c}\text { Ketepatan Media Atau } \\
\text { Sarana Yang Digunakan } \\
\text { Oleh Narasumber }\end{array}$ & 3.73 \\
\hline 4. & $\begin{array}{c}\text { Proses Atau Kegiatan } \\
\text { Pelaksanaan }\end{array}$ & 3.78 \\
\hline 5. & $\begin{array}{c}\text { Penambahan } \\
\text { Pengetahuan/Keterampilan } \\
\text { yang Dapat Diaplikasikan }\end{array}$ & 3.70 \\
\hline
\end{tabular}

Tabel 6. Hasil Pengisian Kuesioner Peserta PKM (Untuk Narasumber) - Bapak Nicholas Wilson, S.E., M.M.

\begin{tabular}{|c|c|c|}
\hline No. & Kriteria & $\begin{array}{c}\text { Nilai } \\
\text { Rata- } \\
\text { Rata }\end{array}$ \\
\hline 1. & $\begin{array}{c}\text { Kemampuan Atau } \\
\text { Penguasaan Terhadap } \\
\text { Materi }\end{array}$ & $\mathbf{3 . 7 0}$ \\
\hline 2. & $\begin{array}{c}\text { Kemampuan Dalam } \\
\text { Menyampaikan Materi }\end{array}$ & $\mathbf{3 . 7 8}$ \\
\hline 3. & $\begin{array}{c}\text { Kemampuan } \\
\text { Menggunakan Metode } \\
\text { Yang Tepat Dengan Materi }\end{array}$ & $\mathbf{3 . 7 3}$ \\
\hline 4. & $\begin{array}{c}\text { Kemampuan Dalam } \\
\text { Menjawab Pertanyaan } \\
\text { Peserta }\end{array}$ & $\mathbf{3 . 6 2}$ \\
\hline 5. & $\begin{array}{c}\text { Kemampuan Menciptakan } \\
\text { Suasana Yang Mendukung } \\
\text { Kegiatan }\end{array}$ & $\mathbf{3 . 6 8}$ \\
\hline
\end{tabular}

Tabel 7. Hasil Pengisian Kuesioner Peserta PKM

(Untuk Materi yang Disampaikan) - Bapak Lanang Diayudha, S.E., M.Env.Mgt

\begin{tabular}{|c|c|c|}
\hline No. & Kriteria & $\begin{array}{c}\text { Nilai } \\
\text { Rata- } \\
\text { Rata }\end{array}$ \\
\hline 1. & $\begin{array}{c}\text { Manfaat Materi Bagi } \\
\text { Peserta }\end{array}$ & $\mathbf{3 . 6 8}$ \\
\hline 2. & $\begin{array}{c}\text { Relevansi Materi Dengan } \\
\text { Tujuan Kegiatan }\end{array}$ & $\mathbf{3 . 7 8}$ \\
\hline 3. & $\begin{array}{c}\text { Ketepatan Media Atau } \\
\text { Sarana Yang Digunakan } \\
\text { Oleh Narasumber }\end{array}$ & 3.73 \\
\hline 4. & $\begin{array}{c}\text { Proses Atau Kegiatan } \\
\text { Pelaksanaan }\end{array}$ & $\mathbf{3 . 7 8}$ \\
\hline 5. & $\begin{array}{c}\text { Penambahan } \\
\text { Pengetahuan/Keterampilan } \\
\text { yang Dapat Diaplikasikan }\end{array}$ & $\mathbf{3 . 7 0}$ \\
\hline
\end{tabular}

Tabel 8. Hasil Pengisian Kuesioner Peserta PKM (Untuk Narasumber) - Lanang Diayudha, S.E., M.Env.Mgt

\begin{tabular}{|c|c|c|}
\hline No. & Kriteria & $\begin{array}{c}\text { Nilai } \\
\text { Rata- } \\
\text { Rata }\end{array}$ \\
\hline 1. & $\begin{array}{c}\text { Kemampuan Atau } \\
\text { Penguasaan Terhadap } \\
\text { Materi }\end{array}$ & $\mathbf{3 . 7 8}$ \\
\hline 2. & $\begin{array}{c}\text { Kemampuan Dalam } \\
\text { Menyampaikan Materi }\end{array}$ & $\mathbf{3 . 6 2}$ \\
\hline 3. & $\begin{array}{c}\text { Kemampuan } \\
\text { Menggunakan Metode } \\
\text { Yang Tepat Dengan Materi }\end{array}$ & $\mathbf{3 . 5 1}$ \\
\hline 4. & $\begin{array}{c}\text { Kemampuan Dalam } \\
\text { Menjawab Pertanyaan } \\
\text { Peserta }\end{array}$ & $\mathbf{3 . 6 2}$ \\
\hline 5. & $\begin{array}{c}\text { Kemampuan Menciptakan } \\
\text { Suasana Yang Mendukung } \\
\text { Kegiatan }\end{array}$ & $\mathbf{3 . 6 2}$ \\
\hline
\end{tabular}

Adapun berdasarkan data hasil analisis terhadap kuesioner yang diisi oleh para peserta seperti yang telah ditampilkan pada Tabel 1 hingga Tabel 8 diatas, maka secara keseluruhan, terdapat beberapa hal yang menjadi inti dari hasil penilaian para peserta, diantaranya adalah: 
1) Berdasarkan kriteria "Manfaat materi bagi peserta" dan "Kemampuan atau penguasaan terhadap materi", para Peserta PKM Alfa Land sudah merasa manfaat materi dan wawasan instruktur sangat baik.

2) Berdasarkan kriteria "Relevansi materi dengan tujuan kegiatan" dan "Kemampuan dalam menyampaikan materi", para peserta PKM merasa penyampaian materi yang diberikan oleh pembicara jika dikaitkan dengan relevansi materi yang diberikan sudah sangat baik dan sesuai dengan tujuan kegiatan yang dilakukan.

3) Berdasarkan kriteria "Ketepatan media atau sarana yang digunakan oleh narasumber" dan "Kemampuan menggunakan metode yang tepat dengan materi", media atau sarana yang digunakan oleh narasumber serta metode yang digunakan sudah tepat dan baik bagi para peserta PKM.

4) Berdasarkan kriteria "Proses atau kegiatan pelaksanaan" dan "Kemampuan dalam menjawab pertanyaan peserta", para Peserta PKM Alfa Land merasa seluruh proses kegiatan pada acara ini sudah berjalan dengan sangat baik.

5) Berdasarkan kriteria "Penambahan pengetahuan/keterampilan yang dapat diaplikasikan" dan "Kemampuan menciptakan suasana yang mendukung kegiatan", para Peserta PKM Alfa Land merasa dengan adanya kegiatan ini pengetahuan peserta semakin bertambah terkait dengan pentingnya peranan leadership, teamwork, team building, implementasi strategi yang efektif serta pencegahan terjadinya mentalitas silo di dalam meningkatkan keberhasilan perusahaan di dalam suatu Industri.

\section{SIMPULAN}

Adapun berdasarkan hasil pengolahan data, serta berdasarkan apa yang telah disampaikan pada kegiatan Pengabdian Kepada Masyarakat (PKM) kali ini, maka penulis dapat menyimpulkan bahwa secara umum dan secara general, kegiatan PKM pada kali ini berjalan dengan baik dan lancar. Selain itu juga, kegiatan Pengabdian Kepada Masyarakat yang dilakukan pada kali ini pun juga di-response serta disambut positif oleh para peserta yang merupakan para Peserta PKM Alfa Land.

Alhasil, berkaitan dengan kegiatan Pengabdian Kepada Masyarakat (PKM) yang telah dilakukan ini, maka Penulis berharap bahwa seluruh materi yang telah disampaikan dan dipaparkan pada kegiatan PKM kali ini dapat semakin membuka dan memperluas wawasan para peserta terkait dengan pentingnya peranan dari Leadership, Teamwork, Team Building, Implementasi Strategi yang Efektif, serta kemampuan perusahaan untuk mampu mengeliminasi ataupun mencegah terjadinya Mentalitas Silo di dalam suatu Perusahaan guna memastikan bahwa perusahaan dapat mencapai tujuan yang diinginkan oleh perusahaan.

\section{DAFTAR PUSTAKA}

Allio, R.J. (2016), "Learning to be a leader", Strategy \& Leadership, Vol. 44 No. 4, pp. 3-9. https://doi.org/10.1108/SL-06-2016$\underline{0041}$

Forsten-Astikainen, R., HurmelinnaLaukkanen, P., Lämsä, T., Heilmann, P. and Hyrkäs, E. (2017), "Dealing with organizational silos with communities of practice and human resource management", Journal of Workplace Learning, Vol. 29 No. 6, pp. 473-489. https://doi.org/10.1108/JWL-042015-0028 
Goswami, M., Agrawal, R.K. and Goswami, A.K. (2020), "Ethical leadership in organizations: evidence from the field", International Journal of Ethics and Systems, Vol. 37 No. 1, pp. 122144. https://doi.org/10.1108/IJOES04-2020-0048

Jaafaripooyan, E., Mosadeghrad, A.M., Ghiasipour, M. and Shaqura, I.I. (2020), "A leadership model for Iranian health-care organizations", Leadership in Health Services, Vol. 33 No. 4, pp. 461-475. https://doi.org/10.1108/LHS-052020-0022

Jacobsen, C.B. and Salomonsen, H.H. (2020), "Leadership strategies and internal communication in public organizations", International Journal of Public Sector Management, Vol. 34 No. 2, pp. 137-154. https://doi.org/10.1108/IJPSM-032020-0086

Kumalo, M. and Scheepers, C.B. (2020), "Leadership of change in South Africa public sector turnarounds", Journal of Organizational Change Management, Vol. 34 No. 1, pp. 137157. https://doi.org/10.1108/JOCM04-2017-0142

Manning, T. and Robertson, B. (2016), "A three factor model of followership: part 1- introduction to followership, leadership and the three factor model of leadership", Industrial and Commercial Training, Vol. 48 No. 6, pp. 277-283. https://doi.org/10.1108/ICT-01-2016$\underline{0003}$
Philip Omondi, M., Ombui, K. and Mungatu, J. (2013), "Factors affecting effective strategy implementation for attainment of Millennium Development Goal 5 by international reproductive health nongovernmental organizations in Kenya", The TQM Journal, Vol. 25 No. 5, pp. 507-519. https://doi.org/10.1108/TQM-102012-0079

Wilson, N., Keni, K., and Tan, P.H.P. (2019). The Effect of Website Design Quality and Service Quality on Repurchase Intention in the E-commerce Industry: A Cross-Continental Analysis, Gadjah Mada International Journal of Business, Vol. 21 No.2, pp. 187-222. https://doi.org/10.22146/gamaijb.336 $\underline{65}$

Zubairu, N., Dinwoodie, J., Govindan, K., Hunter, L. and Roh, S. (2021), "Supply chain strategies as drivers of financial performance in liquefied natural gas networks", Supply Chain Management, Vol. ahead-of-print No. ahead-of-print. https://doi.org/10.1108/SCM-082020-0389 